\title{
The Canary in the Mine: Remote Learning in the Time of COVID-19
}

\author{
David Coker ${ }^{1, *}$ \\ ${ }^{1}$ Fort Hays State University, USA \\ *Correspondence: Fort Hays State University, USA. E-mail: dccoker@fhsu.edu
}

Received: July 27, 2020

Accepted: August 11, 2020 Online Published: August 17, 2020

doi:10.5430/jct.v9n3p76

URL: https://doi.org/10.5430/jct.v9n3p76

\begin{abstract}
National organizations in the United States issued policy proposals for returning to school during the COVID-19 pandemic. A qualitative review, using the constant comparison model, examined six policies from different organizations. The policies operate on the notion of a progressive curriculum, with the values of equity, access, and adaptations driving the planning process. There are five variables national policies utilize to operationalize the progressive curriculum and values: organizing, staffing, scheduling, envisioning, and vulnerabilities. A case study using an individual school district examined the impact on learning within the framework of the policies. Recommendations to improve online and remote learning follow.
\end{abstract}

Keywords: COVID-19, educational policy, curriculum, equity, technology

\section{Introduction}

The response to the novel coronavirus forced schools across the nation to either close or change the way education traditionally operated. Close to one-half of all parents surveyed are concerned with the state of education, as one survey found $22 \%$ of students spent less than one hour per week, with the average being 4.2 hours (Brenan, 2020; Jacobson, 2020). The radical change produced questionable results, with $60 \%$ of students participating regularly, approximately one-third of students missing, and two-thirds to three-fourths of teachers concerned about student engagement and learning (Barnum \& Bryan, 2020; Goldstein, Popescu, \& Hannah-Jones, 2020; K. Graham, 2020).

Schools struggled with a radical transformation of traditional practices to an online environment in a short amount of time (Pell, Cooke, \& Lesser, 2020). The lack of access in the movement to online learning created problems for many students, with a quarter to over fifty percent of students estimated to have difficulties connecting (Auxier \& Anderson, 2020; Salman, 2020). Many school systems struggled with the transformation from face-to-face (F2F) to online education, but there has been little focus on what the new normal will mean for the curriculum and long-term learning.

With little research or planning on the new curriculum, the following study describes and explores the curriculum used in model plans of online and remote learning. Using plans presented by national organizations, a case study presents the problems facing schools during the shift to online and remote learning. First, there will be a qualitative review of national plans. Secondly, there will be a case study on the effects of policies using a large school district. A discussion follows, with policy prescriptions and lessons learned.

\section{Methods}

The method used to study policies for reopening schools in the face of the COVID-19 pandemic centers on one question: What is the plan for F2F, online, and remote learning regarding the implementation of the school curriculum? The model, sample, and data analysis describe the framework for analyzing the different plans. The results are then described, as well as limitations.

\subsection{Model}

A qualitative review of policies by national organizations proceeded from a constant comparison model to simultaneously code and analyze to develop theory (Glaser, 1965). Coding, with three levels of examination, followed the guidelines of Saldaña (2015). Using the guidelines of Boeije (2002), the aim of the study, questions to 
ask, and results were mapped. Two levels guided the study: representation and legitimation (Onwuegbuzie, Leech, \& Collins, 2012).

Grounded theory attempts to not only be objective, but the results must be complete and honor the original meaning of the documents analyzed (Rozas \& Klein, 2010). The aim of the study is to answer how national organizations operationalize the new curriculum as schools shift from F2F to online and remote learning. To explore the plan of the curriculum for online and remote learning, the major aim was further broken down into the following questions: What will be the curriculum? How will schools know students are learning? What will be different from Spring 2020? Results could be useful in developing policies and procedures to maximize student learning.

A search of national policies for returning to school in Fall 2020 was conducted. The results were limited to organizations, with state and local plans not included in the study. A review of each plan provided the data to understand the interaction of returning to school and the curriculum. Coding methods used were the following: in vivo, descriptive, processing, focused, memoing, compare and contrast notes, axial, and substantive coding. The method is not linear, and each policy was read in an alternating fashion to keep comparing and contrasting with other policies.

\subsection{Data Collection}

To find school policies concerning the novel coronavirus, trade journals and organizations were reviewed. Searches were conducted in educational journals and magazines to find suitable policies. Policies selected were from national organizations which developed plans for reopening school in Fall 2020 as a response to the novel coronavirus.

\subsection{Sample}

After conducting a search, six policies met the parameters established. All articles were from national organizations and sought to offer guidance to stakeholders on reopening schools during Fall 2020. To conduct a qualitative review, six national policies, as shown in Table 1, were used. The group included two national teachers' unions, two national administrators' organizations, an educational technology group, and a group focused on school improvement.

Table 1. COVID-19 National Policies

\begin{tabular}{lll}
\hline \multicolumn{1}{c}{ Organization } & \multicolumn{1}{c}{ Title } & Date \\
\hline American Association of School & AASA COVID-19 Recovery Task & June 18, 2020 \\
Administrators (AASA) & Force Guidelines for Reopening & \\
& Schools: An Opportunity to & \\
& Transform Public Education & \multirow{2}{*}{ Restart \& Recovery: Considerations } \\
Council of Chief State School & for Teaching and Learning: & \\
Officials (CCSSO) & Academics & 2020 \\
American Federation of Teachers & A Plan to Safely Reopen America's & \\
(AFT) & Schools and Communities & June 18, 2020 \\
Education Resource Strategies & Decision Points for COVID & \\
(ERS) & Comeback Models & 2020 \\
International Society of Technology & Providing Effective and Equitable & \\
in Education (ISTE) & Digital Learning for all Students: & \\
& Key Considerations for Districts & June 14, 2020 \\
National Education Association & All Hands on Deck: Initial Guidance & Reopening School Buildings \\
(NEA) & & \\
\hline
\end{tabular}

\subsection{Data Analysis}

As listed in Table 1, six national policy proposals on reopening public schools in the fall were analyzed using a constant comparison model. All proposals were downloaded and converted to a Microsoft Word document. Using Microsoft Excel, coding and memoing of the proposals were done simultaneously, and as each successive policy was reviewed, contrasts and comparisons were made regularly. After finishing reviewing all articles, all categories and subgroups were assembled from focused and axial coding. There was a realization some codes were too broad, so codes were further broken down and narrowed by different areas. Wordcloud.com also was used to review the policies, codes, and memos. To check for accuracy and agreement, divergence and convergence were sorted to 
produce theory which fit with the data.

Sometimes qualitative review does not produce a key substantive theory. There ended up being a substantive code which acted as vortex, which was at the heart of all codes and was a driver for the variables and values of the curriculum: progressivism. Though policies differed on many concepts and components, all policies sought a positive, progressive curriculum which would move students forward in school and life by assuming existing grade levels were meaningful and attainable under any proposed system. All variables and valued were placed in the context of systemic change. There were the ideas students would learn more and keep improving regardless of the delivery method. Policies operationalized the national curriculum on three different levels: holistically, by variables, and by values.

\subsection{Interpretation}

Grounded research's penultimate goal is to develop a theory which fits the data, has explanatory power which can be generalized, and shows sufficient density to describe and explain what happened in a useful manner (Charmaz, 2006; Glaser, 1965; Saldaña, 2015). The progressive curriculum serves as an omnipresent theory in all the frameworks. Even though there are disagreements of the details, policy makers acknowledge the crisis and the variables which impact schooling in the time of COVID-19 and schooling in general. What is lacking is a reasonable projection of how the time constraint will make any traditional curriculum impossible and unmanageable for most students.

The holistic curriculum provided a framework for all the policies: Curriculum operates over time and space. The content is the vehicle, and the model is multidimensional. Time would be the x-axis, content the y-axis, and the z-axis would be psychoeducational components of both the student, the teacher, school, and the community. How and when students moved was debated, but schools envisioned the curriculum as linear, with neatly defined grade levels which organized the learning experience. Schools operate on the assumption students are less individuals and more cohorts, with most student moving through time and space at predictable, consistent paces until the end is reached and the school year is over. There was concern online and remote learning would be detrimental to relationships; some policies had more emphasis on relationships than others, but plans stated students need to have "well-being and connections" to teachers, peers, and the community beyond pure academics.

Table 2. Operational Variables

\begin{tabular}{lll}
\hline Categories & Subcategories & Concerns \\
\hline Organizing & $\begin{array}{l}\text { Responsiveness, } \\
\text { diagnosing, designing }\end{array}$ & $\begin{array}{l}\text { Data-driven system, engaging curriculum, new curriculum, } \\
\text { business-public partnerships, extreme personalization, } \\
\text { whole child }\end{array}$ \\
Staffing & $\begin{array}{l}\text { Adaptations, prioritizing, } \\
\text { collaborating }\end{array}$ & $\begin{array}{l}\text { Must change, new teacher roles, involve stakeholders, } \\
\text { fracturing teacher skills, competencies }\end{array}$ \\
Scheduling & $\begin{array}{l}\text { Instructional model, time } \\
\text { commitment, } \\
\text { relationships }\end{array}$ & $\begin{array}{l}\text { Face to face to hybrid or remote, relationship building, } \\
\text { challenging/active/engaging, differentiation, } \\
\text { between models }\end{array}$ \\
toggling \\
Envisioning & $\begin{array}{l}\text { Managing, strategic, } \\
\text { systems, academic goals, } \\
\text { transforming }\end{array}$ & $\begin{array}{l}\text { Monitor adaptations, question assumptions, radical change, } \\
\text { improvement cycles, paradigms }\end{array}$ \\
& $\begin{array}{l}\text { Equality, } \\
\text { compensatory services }\end{array}$ & $\begin{array}{l}\text { Services for most needy or behind, learning loss, response to } \\
\text { intervention, social-emotional learning, required face to face }\end{array}$ \\
\hline
\end{tabular}

The variables, shown in Table 2, which impact the holistic curriculum are the following: envisioning, scheduling, vulnerabilities, staffing, and organizing. The vision should control policies, but the overt vision for many policies is lacking. Having a "north star," "question assumptions," and "data about what we do" were missing in some plans, but the thrust was school would be different from the traditional, online, and hybridized models. What teachers will do varied, as well, with some policies wanting traditional roles and others looking for "teacher leaders" and "new modalities" as old competencies are replaced. Organizing was closely connected with scheduling and staffing, with 
calls for a new curriculum, replete with "essential curriculum," "reducing the length," developing "curated libraries," and using "data-driven" techniques. Though these variables were different to one degree or another, policy makers had agreement to focus on the most vulnerable, which included students in special education, English-language learners, and students in poverty or marginalized.

The values which propel the holistic curriculum and the variables are equity, access, and adaptations. Equity sought to help the "most vulnerable" by "prioritizing" certain subgroups of students, but there was also fear of "resegregation." Also, extra assistance could be "academic remediation," but too much academic remediation could stifle growth as the grade-level curriculum might get supplanted. Equity could be affected by access, as many students do not have computer devices, the Internet, or the means at home to have the space to complete schoolwork. Some policy makers advocated for packets, but others lamented packets are "boring," "easy," and offer "little value." Adaptations would follow from diagnosing and remediating by making school "increasingly personalized and differentiated."

There were several disagreements on how schools would progress, even if the values and variables were acknowledged. The way schools would progress was never operationalized, as the issues appear to be at the local level. Besides the AFT, policy makers stated Spring 2020 was a disaster, and besides ISTE and ERS, no policy offered a sharp rebuke and a need to have a break from the past. How to decide what student needs a teacher and who can go it alone is ill-defined, though younger students seem to need more assistance than older students. Why some students receive more services than others is problematic and would require data streams which either do not exist or are not used. How to produce equity by being inequitable is never delineated, as tracking was long ago abandoned to have one teacher somehow teach students with possibly little in common with peers in the way of academic skills.

The curriculum needs to change, as there is too much with too little time. Online education is boring and counterproductive, and policy makers varied from curated libraries to developing new models to doing what one has always done, only online. The recommendation produces a paradox: If schools can and should whittle the curriculum down to essential knowledge and skills, then why do schools have a curriculum in place which is non-essential? A question can be posed which sheds light on this conundrum: What would a student miss if she only went half a year to $7^{\text {th }}$ grade social studies? Important skill gaps in K-3 would be detrimental, and high-level classes for $10-12^{\text {th }}$ grade, such as Chemistry or Calculus, certainly could not be served by a vastly truncated curriculum. Why do students on level and gifted receive less assistance? What kind of system does not focus on everyone's needs? How will relationships and positive social interaction be maintained?

The time difference is never fully addressed. Most students have been found to not work online, and policy makers address the concern with neither concrete plans nor a roadmap. Schools will start the 2020-2021 school year without a curriculum which fits a schedule of two days per week versus five and lacks a teacher to offer dialogue, discussion, and feedback. There is the assumption of student motivation which had not proven true in Spring 2020. The time problem can be applied on two levels: proximal and distant. The proximal is the grade-level curriculum, and the distant is the K-12 curriculum, which typically requires learning skills and knowledge prior to completing advanced topics in the following years.

Some policy makers suggest, to counter learning loss and the reduced time, the use of extreme differentiation and personalization. There are at least three problems with this proposal: the data streams for robust, timely differentiation does not exist; even if the data streams did exist, teachers neither have the ability nor time to individually tutor every student in every class, especially in an online and remote environment; and extreme differentiation erodes standardization, which can lead all students on a different path and preclude, by rule, the chance of equitable outcomes, as there might not be goals and objectives in common. Extreme differentiation and personalization could lead to the loss of grade levels.

A key assumption underlying the progressive curriculum is learning happens in a linear fashion. One keeps adding to prior knowledge to progressively stair step up to new levels of mastery. There is a problem not all learning is linear. There can be circular and fragmented learning, where discrete parts of the curriculum can influence and impact learning on another line of the curriculum. Also, because there are multiple factors and variables influencing curriculum, a two-dimensional model of moving from one grade to the next might be too simplistic. The model, shown in Figure 1, details the values, guiding principle, and variables which were the curricular framework to reopen schools during the COVID-19 pandemic. 


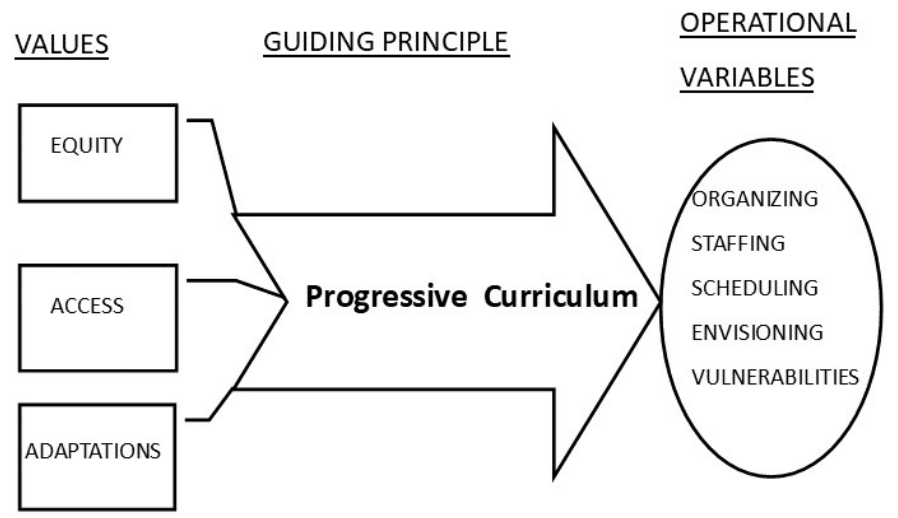

Figure 1. Curriculum Framework to Reopen Schools

Another question remains: If learning loss were real, students would be starting the fourth quarter of the previous year in the fall. If grade-level learning were linear and necessary, then students could not progress unless students had the appropriate skills and knowledge from the previous school year. There is no clarity on what an eight-grade reader can do better than a seventh-grade reader, which points to the often arbitrary order of knowledge and skills. Some might claim math and higher-level skills do show the need for a clear progression, yet experience suggests students without skills get promoted regardless and receive passing grades year after year. The lack of meaningful impact of learning loss also erodes the question of proponents who claim suspension and expulsion reduce educational outcomes. Closing schools in Spring 2020 amounted to a de facto expulsion of all students.

The call for action, as shown in Figure 1, is about a new system which does not exist. Schools, at the K-12 and collegiate level, are ill prepared to provide rich, engaging online or remote instruction which motivates students and sustains the need for social interaction (Seifert, 2020). Responding to student failure has not produced the results hoped for, and removing students from school for lengthy periods of time cannot reasonably be spun as a positive. Progression will be greatly slowed, as time will work against meaningful levels of achievement. Equity, access, and adaptations will be constrained by a system which shifts school to a part-time, go-it-alone endeavor.

\subsection{Limitations}

Legitimation looks at convergence and collaboration to check findings reflect what the authors of the policies intended (Onwuegbuzie, Frels, \& Hwang, 2016). Themes which were drawn from the data and were consistent with findings increase the likelihood of accuracy, and care was taken to move from saturation to repeated searching, coding, and memoing to avoid neglecting emerging themes too hastily (Charmaz, 2006; Patton, 1999; Walsh \& Downe, 2005). Still, all qualitative research depends on the personal beliefs and values of the author (Alexander, 2020). Other researchers, depending on experience, expertise, and ideology, might find different issues.

\section{Case Study}

Case studies are useful if the situation described is complex and relevant, and the results can inform future practices (Fossey \& Crow, 2011). Applied research solves a problem and can explain the theoretical perspective of the situation (Hancock \& Algozzine, 2017). Findings from reviewing the different policies revealed an indifference to the mission of schools - teaching and learning. The context and problems of Chicago SD 299 will be presented, and a policy prescription follows.

\subsection{Context}

Remote learning, for most school districts, was a spectacular failure (Bozkurt et al., 2020). Chicago already suffered from absentee problems, with $24 \%$ of students chronically absent. Chronically absent means absent for $10 \%$ or greater (Illinois Report Card, 2020). When COVID-19 hit, Chicago moved to online and remote learning. While Chicago stated $77 \%$ of students logged on, only $85 \%$ completed at least one assignment per week. Worse yet, $15 \%$ did not $\log$ on at all, and the rates for special education students were even lower (Koumpilova, 2020). In the midst of a rollout with little return, Chicago produced no policy to drastically upset current practices in search of higher student engagement and learning.

Chicago Public Schools' (2020) proposal in response to novel coronavirus allows students to either do all online or 
operate on a 2-1-2 model, of two days face-to-face, one day remote with synchronous learning, and two days online with asynchronous learning. Examining F2F high school to remote or online learning shows the problem. Compared to last semester's participation rate, if students attend seven classes per day in high school at 50 minutes per class, the new model reduces weekly learning from 1750 total minutes to 700 minutes. The $60 \%$ reduction means if students went continuously, the entire semester would last approximately seven weeks (and probably less if school is held in person on Monday, the most common day for holidays). Curriculum would change dramatically, as high school students in US History I would barely get into the 1700s versus the end of the Civil War and elementary students would be even more behind as many students lack the ability to work independently. Over a traditional K-12 school career, at the current pace online of one assignment per week, a student would finish 1.73 years over the 13 years of school. Completing two school days per week would take 32 years to equal the traditional 178-day school year. There is a coming crisis unless the status quo is upset.

The above scenario is optimistic, as any teacher will attest students off for long weekends, like in the 2-1-2 model, need much more time to master a skill than someone attending every day. A much more likely scenario is a $70-80 \%$ reduction in the curriculum. Chicago and others will claim online and remote learning will bridge the gap, but the dismal outcomes of the past (Heppen et al., 2017) offer little data to support anything other than students will not morph into independent, motivated learners able to self-manage oneself without teachers or peers.

The trend of online school in Chicago in the spring suggested students completed one assignment per week. If the trend continued for all online students, probably one-fourth will never show up, and the ones who do, if each student completed an assignment per class would complete approximately 30-40 assignments the entire year. Typically, if there is an assignment per period (there would be much more, as teachers chunk assignments into manageable parts), the reduction in work would be a $97.1 \%$. The $97.1 \%$ is being optimistic, as there is no evidence online and remote learning is as rigorous as F2F learning.

Some students cannot complete work online. Malkus (2020) found only $20 \%$ of schools surveyed provided rigorous instruction, and the schools which offered instructional packets were largely menial work. Without a formal curriculum and teacher and peer learning, instructional packets must either be very easy or require parents and guardians to have the knowledge, skills, and attitude to successfully teach material. From elementary to upper level high school courses, there is no existing model which makes worksheets and packets a viable, meaningful choice. If packets and videos worked, teachers would be irrelevant and a relic of a bygone era.

Students with poor attendance have higher rates of poverty and issues at home, slow down the instruction pace for peers from missing days, and have increased rates of dropping out than predicted by $8^{\text {th }}$ grade test scores (Annie E. Casey Foundation, 2010; Gottfried, 2019). Experts, for the past fifty years, claimed homework should be 10-minutes per grade level and needs to be well designed and meaningful, but many districts eliminated homework because the claim students in poverty were either incapable or suffered from heightened family stress (Allison \& Attisha, 2019; Boser \& Benner, 2019; Marzano \& Pickering, 2007; Pressman et al., 2015). There is a rich irony in current policies: Students cannot complete homework and can barely attend school, but the 10-minute homework rule will be jettisoned for 300 minutes per day independent instruction. Results show the policies are unworkable, unsuccessful, and detrimental to the long-term educational outcomes of students.

Attendance for students in Chicago reveals the following: $67 \%$ miss on average $5 \%$ or less, and $24 \%$ are chronically absent and miss greater than 10\% (Illinois Report Card, 2020). Goodman (2014) found each day missed resulted in a 0.008 standard deviation reduction in scores on standardized tests. If the Spring 2020 rate continues, students will, on average, complete 21.2 additional assignments for the 106 online and, or remote days for the equivalent of 3.03 days. Assuming students attend F2F two days per week (72 days per year on average), complete one assignment for every five days online (with traditional school 178 days per year at 7 classes of 50 minutes each, students attend 106 remote days) and no loss of learning by regular long breaks, Goodman's results suggest the following: The $67 \%$ with good attendance will attend approximately 68.4 days, which will result in a decline on state tests of approximately 0.85 standard deviations. For the chronically absent, the rate could be much higher.

The long-term economic impact could be catastrophic, last decades, and harm individuals and society if the learning loss from COVID-19 continues (Azevedo, Hasan, Goldemberg, Iqbal, \& Geven, 2020; Psacharopoulos, Collis, Patrinos, \& Vegas, 2020). The average instructional time lost under optimal conditions, which are unlikely, will probably be in excess of $60 \%$. One could conjecture certain subjects, such as math, writing, and advanced sciences, will see much steeper declines. Another issue is the Thanksgiving problem: No competent teacher continues the Monday after Thanksgiving as if there was not a four-day weekend. Having a four-day weekend every week will most likely multiply the learning loss measured by Goodman. The cumulative effect year over year will be even 
worse.

\subsection{Policy}

Peter Drucker (1973) spoke about looking for the opportunity in a crisis. Researchers and policy makers identified problems with technology for the past thirty years: management issues, lack of meaningful interaction, and need for research-based instructional practices (Arnesen, Walters, Borup, \& Barbour, 2020). There is concern student safety from neglect and abuse will become invisible online (Tysinger, Tysinger, \& Diamanduros, 2016). Schools can transform instruction, including when schools resume face-to-face, into a much more efficient, student-centered environment. The old way of everyone doing the same function needs to be reformulated, as the online duplication is a waste of time. Partnerships must assist revamping the opportunities for students, and the entire process should center around the end-user experience. A danger exists in eliminating grade levels or not giving letter grades, as the traditions of the past are the anchors which guide parents. Care must be taken to not disconnect the past as much as honor it.

There are numerous recommendations which could integrate technology and education: collaboration between staff members, efficiency through robust technology implementation, research-based instruction, and high expectations (Coker, 2020). Technology needs to be the bridge to efficiency and effectiveness. Learning management systems need to be one-stop shopping for all school functions. Educators need interactive, engaging, and interesting content to offer, as discussed by the International Society of Technology in Education (2020). School staff members are overwhelmed, so districts, universities, and vendors will need to collaborate to develop curated libraries, so teachers can worry more about instruction than trying to develop content with videos, games, quests, and frequent feedback while simultaneously being online. Having a single sign-on, content, teaming by educators, and real-time feedback with video popups, instant messages, text messages, and chats are some possibilities.

Teachers, not programs and top-down initiatives, should drive improvement. Teräs et al. (2020) stated: "Instead, what should be invested in for the long run, is teachers' pedagogical expertise to design and teach engaging online learning. After all, they are the ones teaching, not the technology" (pp. 6-7). Getting rid of the status quo will not be easy, as many schools continue with the current failure because there is fear of any change. Online and remote school must move beyond high-tech worksheets with more similarities than differences to correspondence school. All policies described the need for adaptations and transformations of current practices, but there were no detailed plans. Most policy makers left decisions at the local level, but there is concern local leaders will neither have the resources nor expertise to confront such pressing matters.

The traditional curriculum will have to change, but the curriculum is too bloated and requires teachers to cover the curriculum versus allowing students to master objectives (Sullo, 2009). What is the feasibility of addressing 200 standards and 3,093 benchmarks within the present education system (Marzano \& Kendall, 1998; Schmoker \& Marzano, 1999), with a $40-70 \%$ reduction in time? Schools will have to move a curriculum to $25 \%$ of existing capabilities, and small classrooms and online opportunities should provide the chance to maximize tutoring opportunities and individualization. The Council of Chief State School Officials (2020) provides a framework to transform curriculum to adapt to remote or online, face-to-face, and hybrid, all within the confines of reduced time while admitting much of what is taught is not essential to a student's success.

The amount of non-teaching staff in schools, including administrators, coordinators, coaches, teaching assistants, librarians, school counselors, social workers, school psychologists, and many other positions, comprise about $50 \%$ of all teaching staff (Perry, 2015; Richmond, 2014; Scafidi, 2017). The 276,000 public teachers nationally (National Center for Education Statistics, 2017) could be reduced to 39,000 based upon student online participation unless major restructuring occurs. Online, the individual classroom needs to be demolished for the one-room schoolhouse. Teachers need integrated vertically and horizontally as well as most staff members returning to the classroom.

An example shows how the new structure could be operationalized. A solitary $5^{\text {th }}$ grade classroom teacher planning her class and seeing few students could be replaced with $4^{\text {th }}$ through $6^{\text {th }}$ grade teachers cooperating to reach all students; students could be placed higher or lower for tutoring as needed. Instead of each teacher designing instruction and only being available for a small group, the power of the collective would be unleashed. When non-teaching staff would be included, educators would be freed from individually figuring out everything and limiting availability for students who need help. Cooperation could happen within and between schools and with other districts. Tear down the classroom walls.

To be successful online, schools need to reorganize in the face of unprecedented barriers, as the new structure can increase teachers' workload and worsen accessibility and equity issues (Carver, 2020; Kaden, 2020). Schools need to 
create the world's biggest, best-staffed classroom at each student's fingertips. The new school tears down walls and makes students the key: Dozens of staff members tutoring in one class, supported by thousands developing the curriculum, with students placed by need, not grade and age, all at the speed of technology. Students should drive the system, and classrooms could change activities in real time based on student need.

For most students, online and remote learning lacks the social factor and is beyond boring, as stated by all policies reviewed, with face-to-face interactivity and engagement being replaced by isolation (Barbour \& Plough, 2009; Barnum \& Bryan, 2020; Weybright, Schulenberg, \& Caldwell, 2020). Instruction with school staff members working together makes synchronous education or a hybrid model more realistic. Remote learning must focus on the components of high-class tutoring, as Hattie and Timperley (2007) stated effective feedback is given frequently, points to a future direction, and improves processes. The static "worksheet approach" and extreme isolation needs to be jettisoned. Schools need to think Xbox or Play Station, not assigning a reading passage, answering questions, and waiting for the teacher to respond.

Teachers struggle translating research into practice (Booher, Nadelson, \& Nadelson, (2020), so action research might be a way to bridge the gap (Somekh, 2005). Future research needs to look at pedagogy, with technology as the tool to deliver instruction. Frequent interaction and engagement would be with any staff member available, and peer contact could be increased and harnessed. Chunking and modularity of every assignment would be drivers in giving feedback in real time. Differentiation could happen, as instruction would be individualized. If instruction is interesting and social, there could be a turnaround. Another key component of future research is measuring satisfaction of both students and parents or guardians. All the ideas exist in traditional school, but there is no clear path to online or remote learning.

Much of what is being implemented lacks research and shows poor results, with no clear federal standard for the transition to online and remote learning (Clancy \& Sentance, 2020). The Organization for Economic Cooperation and Development (OECD) found students, accounting for backgrounds, do a lot worse when put on computer-based platforms. Indeed, a study about fourth graders using tablets for reading scored, on average, a grade level worse (Wexler, 2019). The current model is ineffective and provides little chance for the majority of students being prepared for the current grade or the next school year (Hill, 2020). The return on investment is so poor and laborious, schools might be better off dissolving and waiting until face-to-face instruction resumes.

\section{Conclusion}

Before modern technology, miners would take canaries into the mines to check for methane and poisonous gases, and if the canary became sick or died, miners knew there was a dangerous problem (Chalk, 1982; Pollock, 2016). For decades, school staff members heard data-driven instruction would improve outcomes, but teachers and schools have been unable to translate action into results (Gleason et al., 2019; Neuman, 2016). Results of learning in Spring 2020 should be the canary in the mine which drive planning during the COVID-19 pandemic, yet most schools and policy leaders do not address the harm to the curriculum and future learning. Wants, not data, seem to drive planning, and the progressive curriculum is more dream than reality.

Alvy (2017) stated pedagogy, not technology dominance or other top down, quick fixes, drives change and improvement in education. A progressive curriculum is only possible if teachers have the time and ability to plan, effective management skills, and new instructional methods (C. Graham, Borup, Pulham, \& Larsen, 2019). The challenge is exacerbated by students preferring traditional school over online or blended learning, with the hypothesis lack of social support and timely feedback being reasons for unsuccessful experiences (Alvarado-Alcantar, Keeley, \& Sherrow, 2018; Mills, Baker, Wakefield, \& Angnakoon, 2018). Instead of upholding the status quo, educators must focus on honoring the mission of schools: learning. Unfortunately, many schools plan to continue the same failed policies and practices. If the reduced trend lasts for a year or more, the entire definition of what school looks like and the results planned will have to be reformulated.

\section{References}

Alexander, P. A. (2020). Methodological guidance paper: The art and science of quality systematic reviews. Review of Educational Research, 90(1), 6-23. https://doi.org/ 10.3102/0034654319854352

Allison, M. A., \& Attisha, E. (2019). The link between school attendance and good health. Pediatrics, 143(2). https://doi.org/10.1542/peds.2018-3648

Alvarado-Alcantar, R., Keeley, R., \& Sherrow, B. (2018). Accessibility and usability of preferences in blended 
learning for students with and without disabilities in high school. Journal of Online Learning Research, 4(2), 173-198. Association for the Advancement of Computing in Education (AACE). Retrieved from https://www.learntechlib.org/primary/p/181294/

Alvy, H. (2017). Fighting for change in your school: How to avoid fads and focus on substance. ASCD.

American Association of School Administrators. (2020). AASA COVID-19 recovery task force guidelines for reopening schools: An opportunity to transform public education. Retrieved from https://www.aasacentral.org/

American Federation of Teachers. (2020). A plan to safely reopen America's schools and communities. Retrieved from https://www.aft.org/

Annie E. Casey Foundation. (2010). Early warning! Why reading by the end of third grade matters. Retrieved from https://www.aecf.org/

Arnesen, K., Walters, S., Borup, J., \& Barbour, M. K. (2020). Irrelevant, overlooked, or lost? Trends in 20 years of uncited and low-cited K-12 online learning articles. Online Learning, 24(2). https://doi.org/10.24059/olj.v24i2.2080

Auxier, B., \& Anderson, M. (2020, March 16). As schools close due to the coronavirus, some U.S. students face a digital 'homework gap.' Fact Tank. Retrieved from https://www.pewresearch.org/

Azevedo, J. P., Hasan, A., Goldemberg, D., Iqbal, S. A., \& Geven, K. (2020). Simulating the potential impacts of covid-19 school closures on schooling and learning outcomes: A set of global estimates. Policy Research Working Paper. https://doi.org/10.1596/1813-9450-9284

Barbour, M., \& Plough, C. (2009). Helping to make online learning less isolating. TechTrends, 53(4), 57. https://doi.org/10.1007/s11528-009-0307-5

Barnum, M., \& Bryan, C. (2020). America's great remote learning experiment: What surveys of parents and teachers tell us about how it went. Chalkbeat. Retrieved from https://www.chalkbeat.org/

Boeije, H. (2002). A purposeful approach to the constant comparative method in the analysis of qualitative interviews. Quality and Quantity, 36(4), 391-409. https://doi.org/10.1023/a:1020909529486

Booher, L., Nadelson, L. S., \& Nadelson, S. G. (2020). What about research and evidence? Teachers' perceptions and uses of education research to inform STEM teaching. The Journal of Educational Research, 1-13. https://doi.org/10.1080/00220671.2020.1782811

Boser, U., \& Benner, M. (2019). Homework and higher standards. Center for American Progress. Retrieved from https://www.americanprogress.org/

Bozkurt, A., Jung, I., Xiao, J., Vladimirschi, V., Schuwer, R., Egorov, G., ... \& Rodes, V. (2020). A global outlook to the interruption of education due to COVID-19 pandemic: Navigating in a time of uncertainty and crisis. Asian Journal of Distance Education, 15(1), 1-126. Retrieved from http://www.asianjde.org/

Brenan, M. (2020, March 31). 42\% of parents worry COVID-19 will affect child's education. Gallup. Retrieved from https://news.gallup.com/poll/305819/parents-worry-covid-affect-child-education.aspx

Carver, L. B. (2020). Supporting learners in a time of crisis. Advances in Social Sciences Research Journal, 7(4), 129-136. https://doi.org/10.14738/assrj.74.8109

Chalk, R. (1982). The miners' canary. Bulletin of the Atomic Scientists, 38(2), 16-22. https://doi.org/10.1080/00963402.1982.11455698

Charmaz, K. (2006). Constructing grounded theory: A practical guide through qualitative analysis. Sage.

Chicago Public Schools. (2020). School reopening 2020: Preliminary framework. Retrieved from https://www.cps.edu/

Clancy, D. S., \& Sentance, M. (2020). Keeping students academically engaged during the coronavirus crisis--part one. Policy brief. Pioneer Institute for Public Policy Research. Retrieved from http://www.pioneerinstitute.org

Coker, D. C. (2020). Revolution in remote learning: A plan for radical improvement. In EdMedia+ Innovate Learning (pp. 329-343). Association for the Advancement of Computing in Education (AACE).

Council of Chief State School Officials. (2020). CCSSO supporting states amid coronavirus outbreak. Retrieved from https://www.ccsso.org/

Drucker, P. (1973). Management: Tasks, responsibilities, practices. Harper \& Row Publishers. 
Education Resources Strategies. (2020). COVID comeback models. Retrieved from https://www.erstrategies.org/

Fossey, R., \& Crow, G. M. (2011). The elements of a good case. Journal of Cases in Educational Leadership, 14(3), 4-10. https://doi.org/10.1177\%2F1555458911426467

Glaser, B. G. (1965). The constant comparative method of qualitative analysis. Social Problems, 12(4), 436-445. https://doi.org/10.2307/798843

Gleason, P., Crissey, S., Chojnacki, G., Zukiewicz, M., Silva, T., Costelloe, S., \& O'Reilly, F. (2019). Evaluation of support for using student data to inform teachers' instruction. NCEE 2019-4008. National Center for Education Evaluation and Regional Assistance. Retrieved from https://ies.ed.gov/ncee/pubs/20194008/

Goldstein, D., Popescu, A., \& Hannah-Jones, N. (2020, April 6). As school moves online, many students stay logged out. The New York Times. Retrieved from https://www.nytimes.com/2020/04/06/us/coronavirus-schools-attendance-absent.html

Goodman, J. (2014). Flaking out: Student absences and snow days as disruptions of instructional time (No. w20221). National Bureau of Economic Research. Retrieved from https://www.nber.org/

Gottfried, M. A. (2019). Chronic absenteeism in the classroom context: Effects on achievement. Urban Education, 54(1), 3-34. https://doi.org/10.1177\%2F0042085915618709

Graham, C. R., Borup, J., Pulham, E., \& Larsen, R. (2019). K-12 Blended teaching readiness: Model and instrument development. Journal of Research on Technology in Education, 51(3), 239-258. https://doi.org/10.1080/15391523.2019.1586601

Graham, K. (2020, May 14). Who's showing up for school during the pandemic? In Philly, it's just over half of students. Inquirer.

Retrieved

from https://www.inquirer.com/education/coronavirus-philadelphia-school-district-attendance-learning-20200514.ht $\mathrm{ml}$

Hancock, D. R., \& Algozzine, B. (2017). Doing case study research: A practical guide for beginning researchers. Teachers College Press.

Hattie, J., \& Timperley, H. (2007). The power of feedback. Review of Educational Research, 77(1), 81-112. https://doi.org/10.3102\%2F003465430298487

Heppen, J. B., Sorensen, N., Allensworth, E., Walters, K., Rickles, J., Taylor, S. S., \& Michelman, V. (2017). The struggle to pass algebra: Online vs. face-to-face credit recovery for at-risk urban students. Journal of Research on Educational Effectiveness, 10(2), 272-296. https://doi.org/10.1080/19345747.2016.1168500

Hill, P. T. (2020, May 6). During COVID-19, underperforming school districts have no excuse for standstill on student learning. Brown Center Chalkboard. Retrieved from https://www.brookings.edu/blog/brown-center-chalkboard/

Illinois Report Card. (2020). Chicago Public Schools. Retrieved from https://www.illinoisreportcard.com/

International Society of Technology in Education. (2020). Providing effective and equitable digital learning for all students: Key considerations for districts. Retrieved from https://www.iste.org/

Jacobson, L. (2020, May 20). Survey: Children's loss of social ties, learning are parents' top closure concerns. Education Dive. Retrieved from https://www.educationdive.com/

Kaden, U. (2020). COVID-19 school closure-related changes to the professional life of a K-12 teacher. Education Sciences, 10(6), 165. https://doi.org/10.3390/educsci10060165

Koumpilova, M. (2020, May 27). Nearly 4 out of 5 Chicago students are logging on to do schoolwork, but not all participate equally. Chalkbeat Chicago. Retrieved from https://www.chicago.chalkbeat.org/

Malkus, N. (2020). School districts' remote-learning plans may widen student achievement gap. Education Next, 20(3). Retrieved from https://www.educationnext.org/

Marzano, R. J., \& Kendall, J. S. (1998). Awash in a sea of standards. Aurora, CO: Mid-continent Research for Education and Learning.

Marzano, R. J., \& Pickering, D. J. (2007). Special topic: The case for and against homework. Educational Leadership, 64(6), 74-79.

Mills, L. A., Baker, L., Wakefield, J. S., \& Angnakoon, P. (2018). How do high school students prefer to learn? In 
Digital Technologies: Sustainable Innovations for Improving Teaching and Learning (pp. 95-110). Springer. https://doi.org/10.1007/978-3-319-73417-0_6

National Center for Education Statistics. (2017). Teacher trends. Retrieved from https://nces.ed.gov/fastfacts/display.asp?id=28

National Education Association. (2020). All hands on deck: Initial guidance regarding reopening school buildings. Retrieved from https://www.nea.org/

Neuman, S. B. (2016). Code red: The danger of data-driven instruction. Educational Leadership, 74(3), 24-29.

Onwuegbuzie, A. J., Frels, R. K., \& Hwang, E. (2016). Mapping Saldaña's coding methods onto the literature review process. Journal of Educational Issues, 2(1), 130-150. https://doi.org/10.5296/jei.v2i1.8931

Onwuegbuzie, A. J., Leech, N. L., \& Collins, K. M. (2012). Qualitative analysis techniques for the review of the literature. Qualitative Report, 17, 56. Retrieved from https://nsuworks.nova.edu/tqr/

Patton, M. Q. (1999). Enhancing the quality and credibility of qualitative analysis. Health Services Research, 34(5Pt2), 1189-1208. Retrieved from https://www.ncbi.nlm.nih.gov/pmc/articles/PMC1089059/

Pell, M. B., Cooke, K., \& Lesser, B. (2020, June 2). COVID's school daze. Reuters Investigates. Retrieved from https://www.reuters.com/

Perry, M. J. (2015). Chart of the day: Administrative bloat in US public schools. AEIdeas. Retrieved from https://www.aei.org/

Pollock, C. (2016). The canary in the coal mine. Journal of Avian Medicine and Surgery, 30(4), 386-391. https://doi.org/10.1647/1082-6742-30.4.386

Pressman, R. M., Sugarman, D. B., Nemon, M. L., Desjarlais, J., Owens, J. A., \& Schettini-Evans, A. (2015). Homework and family stress: With consideration of parents' self confidence, educational level, and cultural background. The American Journal of Family Therapy, 43(4), 297-313. https://doi.org/10.1080/01926187.2015.1061407

Psacharopoulos, G., Collis, V., Patrinos, H. A., \& Vegas, E. (2020). Lost wages: The COVID-19 cost of school closures. World Bank Policy Research Working Paper, (9246). Retrieved from https://ssrn.com/abstract=3601422

Richmond, M. (2014). The hidden half: School employees who don't teach. Thomas B. Fordham Institute. Retrieved from https://fordhaminstitute.org/

Rozas, L. W., \& Klein, W. C. (2010). The value and purpose of the traditional qualitative literature review. Journal of Evidence-Based Social Work, 7(5), 387-399. https://doi.org/10.1080/15433710903344116

Saldaña, J. (2015). The coding manual for qualitative researchers. Sage.

Salman, J. (2020). Hundreds of thousands of students still can't access online learning. Hechinger Report. Retrieved from https://www.hechingerreport.com

Scafidi, B. (2017). Back to the staffing surge. Ed Choice. Retrieved from https://www.edchoice.org/

Schmoker, M., \& Marzano, R. J. (1999). Realizing the promise of standards-based education. Educational Leadership, 56, 17-21. http://www.ascd.org/ publications/educational-leadership.aspx

Seifert, T. (2020). Improving involvement, engagement and sense of belonging through synchronous instruction during Covid-19. In EdMedia+ Innovate Learning (pp. 98-105). Association for the Advancement of Computing in Education (AACE).

Somekh, B. (2005). Action research: A methodology for change and development: a methodology for change and development. McGraw-Hill Education (UK).

Sullo, B. (2009). The motivated student: Unlocking the enthusiasm for learning. ASCD.

Teräs, M., Teräs, H., Arinto, P., Brunton, J., Daryono, D., \& Subramaniam, T. (2020). COVID-19 and the push to online learning: Reflections from 5 countries. Digital Culture \& Education. Retrieved from https://www.digitalcultureandeducation.com/

Tysinger, D., Tysinger, J. A., \& Diamanduros, T. D. (2016). Crisis events in K-12 online learning: Educator perceptions and preparedness. National Youth-At-Risk Journal, 2(1), 41. https://doi.org/10.20429/nyarj.2016.020104 
Walsh, D., \& Downe, S. (2005). Meta-synthesis method for qualitative research: A literature review. Journal of Advanced Nursing, 50(2), 204-211. https://doi.org/10.1111/j.1365-2648.2005.03380.x

Wexler, N. (2019). How classroom technology is holding students back. MIT Technology Review. Retrieved from https://www.technologyreview.com/

Weybright, E. H., Schulenberg, J., \& Caldwell, L. L. (2020). More bored today than yesterday? National trends in adolescent boredom from 2008 to 2017. Journal of Adolescent Health, 66(3), 360-365. https://doi.org/10.1016/j.jadohealth.2019.09.021

\section{Copyrights}

Copyright for this article is retained by the author(s), with first publication rights granted to the journal.

This is an open-access article distributed under the terms and conditions of the Creative Commons Attribution license (http://creativecommons.org/licenses/by/4.0/). 